\title{
Effects of Leaf Extract of Lantana camara on Germination and Growth Behavior of Selected Tree Species
}

\author{
K. Abha Manohar ${ }^{1 *}$, Neelam Khare ${ }^{2}$ and Hemant Kumar ${ }^{2}$ \\ ${ }^{1}$ Department of Forestry, School of Forestry, College of Forestry, SHUATS, \\ Allahabad, Uttar Pradesh, India \\ ${ }^{2}$ College of Forestry, SHUATS, Allahabad, Uttar Pradesh, India \\ *Corresponding author
}

\section{A B S T R A C T}

\begin{tabular}{|l|}
\hline Ke y w o r d s \\
Allelopathy, \\
Lantana, \\
Germination \\
inhibition, Tree \\
species. \\
\hline Article Info \\
\hline $\begin{array}{l}\text { Accepted: } \\
\text { 23 June } 2017 \\
\text { Available Online: } \\
\text { 10 July } 2017\end{array}$ \\
\hline
\end{tabular}

\section{Introduction}

Exotic invasive weeds has become a global issue owing to the wide spread and tremendous growth overcoming the native flora. Lantana camara is a prime and notorious perennial thorny shrub of the family verbenaceae which is native to the American tropics commonly known as wild sage. In India also it has wide reach in agricultural, forest, community land and waste lands. The invasion of new territories by alien plant species threatens the biodiversity and the stability of the ecosystems (Davis, 2003). Invasion is considered as the second most widespread threat to global biodiversity next to habitat destruction (Leadley et al., 2010).
As the density of Lantana camara in forest increases, allelopathic interactions increase and hence there is decline in species richness (Day et al., 2003). Allelochemicals are plant secondary metabolites normally released into the environment through volatilization, leaching, root exudation and decomposition of plant residues in the soil (Khalaj et al., 2013). Weeds species are often rich sources of secondary metabolites (allelochemicals) and these chemicals modify the environment of other plants growing in their vicinity and this phenomenon is known as allelopathy (Nandal et al., 1994). Allelopathy has traditionally been considered only the 
negative chemical warfare of one organism upon another (Bansal, 1994). The different parts of lantana contain allelochemicals mainly aromatic alkaloids and phenolic compounds (Ambika et al., 2003) which can interfere with seed germination and early growth of many plant species (Sahid and Sugau, 1993; Gentle and Duggin, 1997; Sharma et al., 2005; Ahmed et al., 2007).

Lantana can also interfere growth of nearby plants by outcompeting for soil nutrients (Dobhal, et al., 2010) and altering microenvironment by forming dense thickets (Sharma and Raghubanshi, 2007). Allelopathy is a form of plant interference that can significantly influence ecosystem and agro ecosystem dynamics (Michelangelo et al., 2016).

Researches have been done on the allelopathic effect of Lantana camara on crops but very few researches has done on tree species. Therefore the experiment was conducted to explore the allelopathic effect of Lantana camara leaf extracts on selected tree species.

\section{Materials and Methods}

The experiment was carried out at laboratory of College of Forestry, Sam Higginbottom University of Agriculture Technology and Sciences (SHUATS), Allahabad-U.P. In the present study we have used Lantana camara as the donor plant. The experiment was designed in Completely Randomized Design (CRD) in the laboratory with different concentrations of leaf extract (control, 10\%, $20 \%, 30 \%$ and $40 \%$ ) labeled as $\mathrm{T}_{0}, \mathrm{~T}_{1}, \mathrm{~T}_{2}, \mathrm{~T}_{3}$ and $\mathrm{T}_{4}$ respectively and replicated four times.

\section{Preparation of leaf extract}

For the preparation of leaf extracts $100 \mathrm{~g}$ of dry leaves was soaked in $500 \mathrm{~mL}$ distilled water and kept in $28^{\circ} \mathrm{C}$ room temperature for
24 hours. The solution was filtered through double layered muslin cloth. The filtrate was again filtered through Whatman No.1 filter paper into a conical flask. This solution was diluted to make $10 \%, 20 \%, 30 \%$ and $40 \%$ (on the basis of volume) and used for seed treatment.

The experiment was carried out in sterile petridishes of $12 \mathrm{~cm}$ in size placing double layered Whatman No.1 filter paper on petridishes. The extract of each concentration was added to each petridish of respective treatment daily in such an amount just enough to wet the seeds. The control was treated only with distilled water. 10 seeds each of Albizia lebbeck and Dalbergia sissoo were placed in the petridish replicating 4 times and was set in the laboratory. The experiment was extended over a period of 30 days to allow the germination of last seed and the measurement of the shoot and root length.

The seed was considered as germinated, when radical emerged. The germination was recorded daily and the results were determined by counting the number of germinated seeds and measuring the length of primary root and main shoot. The biomass was calculated by taking the fresh of roots and shoots.

\section{Germination and growth behavior}

In the experiment data on germination percentage, root and shoot length, fresh weight of root and shoot, and vigour index (Abdul and Anderson, 1973) were observed.

Finally, the average data obtained from the experiment was subjected to analysis of variance using OPSTAT (Sheoran et al., 1998) at 0.05 probability level. On the emergence of radicle a seed was considered to be germinated. Germination was recorded daily and results were determined by counting the number of seeds germinated. 


\section{Results and Discussion}

\section{Germination}

The germination percent of the two selected tree species is shown in table 1. Variation of germination percent was in accordance with the concentration of leaf extract and the increase of concentration, the inhibitory effect also increased. The maximum inhibitory effect in Albizia was (43.3\%) and in Dalbergia sissoo was $(97.05 \%)$ seen in $\mathrm{T}_{4}$ treatment at $40 \%$ concentration. The highest germination ratio $(85 \%)$ was found on Dalbergia sissoo at $\mathrm{T}_{0}$ treatment followed by Albizia lebbeck $(75 \%)$ at the same treatment. The minimum germination percent $(2.5 \%)$ was in Dalbergia sissoo at $40 \%$ concentration $\left(\mathrm{T}_{4}\right)$. Among the receptor tree species Albizia lebbeck is less sensitive towards the treatments as compared to Dalbergia sissoo. It was observed that the Lantana camara leaf extracts significantly reduced the germination percentage in Albizia lebbeck and Dalbergia sissoo compared to the control (Distilled Water) treatment. These results were similar to the findings of Hossain and Alam (2010) that the different concentrations of Lantana camara leaf extracts caused significant inhibitory effect on germination of forest crops Acacia auriculiformis, Paraserianthes falcataria, Albizia procera. The allelopathic effect of Parthenium hysterophorous on germination of multipurpose tree species (Swaminathan et al., 2012) (Fig. 1).

\section{Growth behaviors}

\section{Shoot elongation (cm)}

The average shoot length of the germinated seedlings of Forest tree species in all the treatments are shown in table 1. The study revealed that inhibition of shoot length in Albizia lebbeck and Dalbergia sissoo was progressively increased with the increase of concentration. Statistically pronounced significant effect was found at all the treatments (Fig. 2). Maximum inhibition was observed in Albizia lebbeck (0.02) compared to Dalbergia sissoo (0.03) at $\mathrm{T}_{4}(40 \%)$. Maximum elongation of shoot $(2.30 \mathrm{~cm})$ was observed in Dalbergia sissoo followed by Albizialebbeck (2.22) at $\mathrm{T}_{0}$ (control).

\section{Root elongation}

The root length of the bioassay species were found to be greatly inhibited with the increase of the concentration of extract. The inhibitory effect was much more pronounced at $\mathrm{T}_{4}$ treatment followed by $\mathrm{T}_{3}, \mathrm{~T}_{2}$ and $\mathrm{T}_{1}$ treatments respectively. Maximum inhibition was occurred in Albizia lebbeck $(0.10)$ at $\mathrm{T}_{4}$ treatment. Maximum elongation of root (1.40 $\mathrm{cm})$ was observed in Dalbergia sissoo followed by Albizia lebbeck $(0.51 \mathrm{~cm})$ both at control (Fig. 2).

\section{Fresh weight of shoot}

The fresh shoot weight of the bioassay species were found to be profoundly reduced with the increase of the extract concentration. The inhibitory effect was much more pronounced at $\mathrm{T}_{4}$ treatment followed by $\mathrm{T}_{3}, \mathrm{~T}_{2}$ and $\mathrm{T}_{1}$ treatments respectively. Both the species were inhibited equally i.e. Albizia lebbeck (0.002) and Dalbergia sissoo $(0.002)$ at $\mathrm{T}_{4}$ treatment. Maximum fresh shoot weight $(0.085 \mathrm{~g})$ was observed in Albizia lebbeck followed by Dalbergia sissoo $(0.064 \mathrm{~g})$ both at control (Fig. 3).

\section{Fresh weight of root}

The fresh root weight of the bioassay species were found to be profoundly reduced with the increase of the extract concentration. The inhibitory effect was much more pronounced at $\mathrm{T}_{4}$ treatment followed by $\mathrm{T}_{3}, \mathrm{~T}_{2}$ and $\mathrm{T}_{1}$ treatments respectively. 
Fig.1 Effects of treatments on germination \%

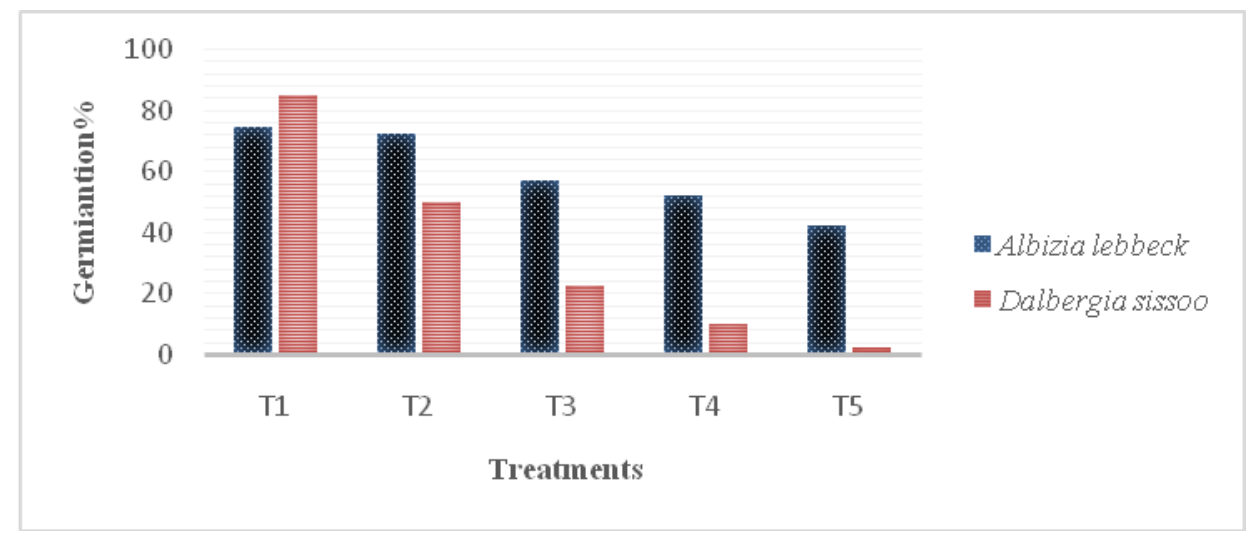

Fig.2 Effect of leaf extract on root and shoot elongation

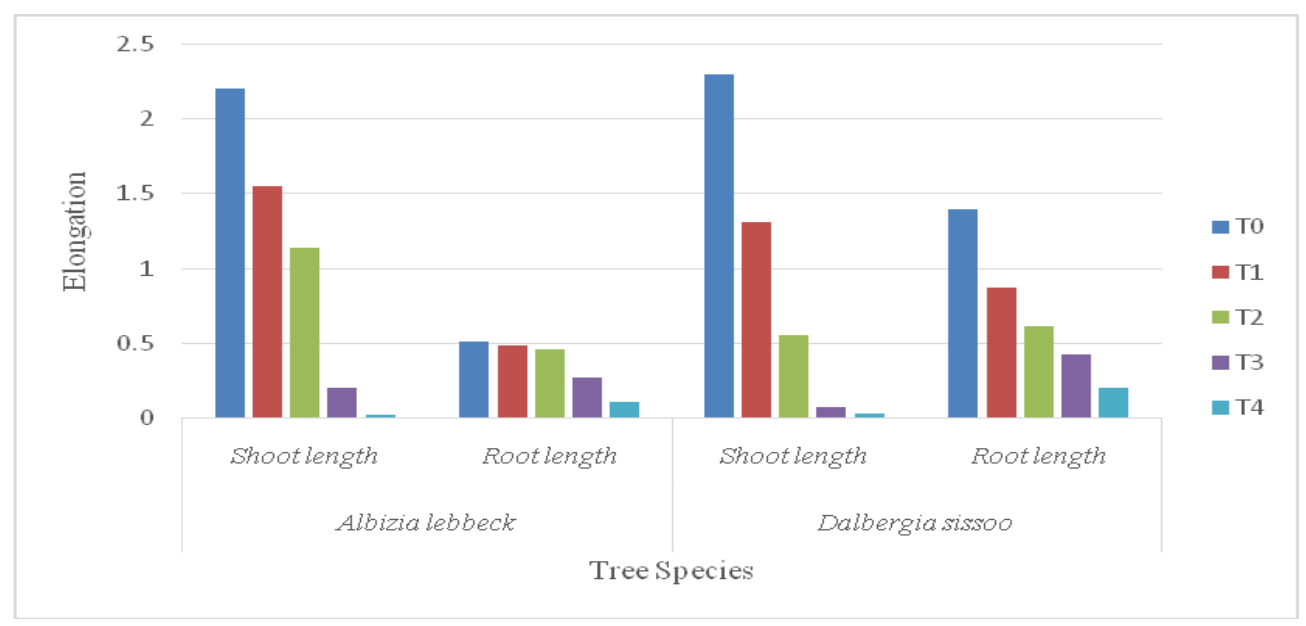

Fig.3 Effect of leaf extract on fresh shoot and root weight

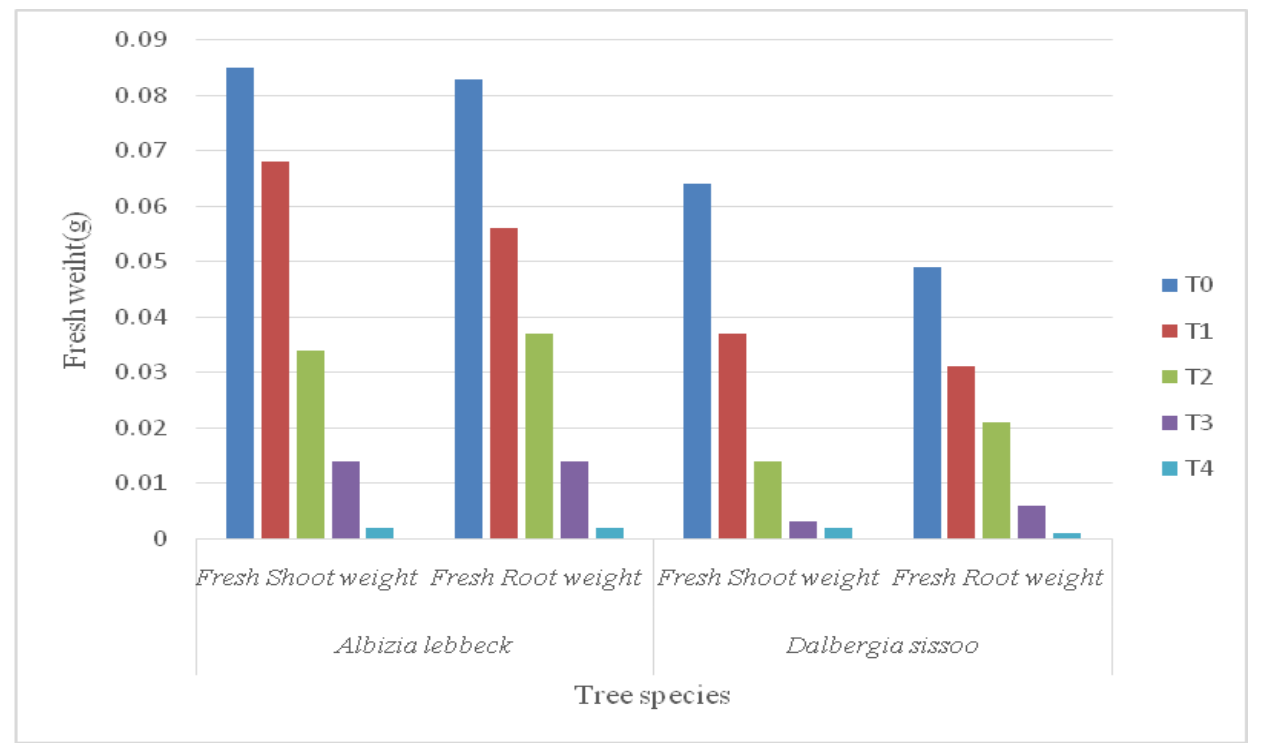


Fig.4 Vigour index of tree species on various treatments

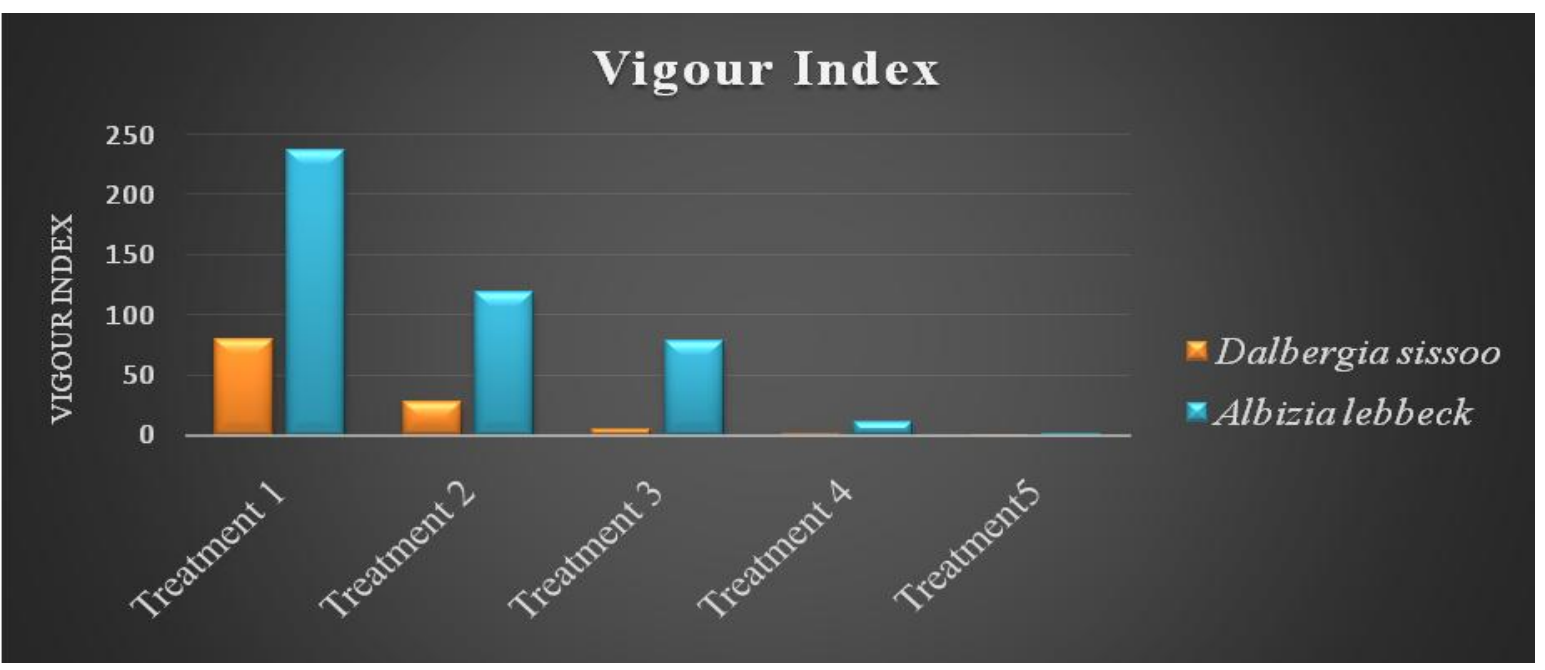

Table.1 Germination and growth behavior of forest tree species to various treatment concentrations

\begin{tabular}{|l|l|l|l|l|l|l|l|}
\hline Tree Species & $\begin{array}{l}\text { Concent } \\
\text { ration } \\
\text { Level }\end{array}$ & $\begin{array}{l}\text { Germinatio } \\
\mathrm{n} \%\end{array}$ & $\begin{array}{l}\text { Shoot } \\
\text { length }\end{array}$ & $\begin{array}{l}\text { Root } \\
\text { Length }\end{array}$ & $\begin{array}{l}\text { Fresh } \\
\text { Shoot } \\
\text { weight }\end{array}$ & $\begin{array}{l}\text { Fresh } \\
\text { Root } \\
\text { weight }\end{array}$ & $\begin{array}{l}\text { Vigour } \\
\text { Index }\end{array}$ \\
\hline \multirow{4}{*}{ A. lebbeck } & Control & 75 & 2.22 & 0.51 & 0.085 & 0.083 & 236.87 \\
\cline { 2 - 8 } & T1 & 72.5 & 1.55 & 0.48 & 0.068 & 0.056 & 119.48 \\
\cline { 2 - 8 } & T2 & 57.5 & 1.14 & 0.46 & 0.034 & 0.037 & 78.62 \\
\cline { 2 - 8 } & T3 & 52.5 & 0.20 & 0.27 & 0.014 & 0.014 & 11.30 \\
\cline { 2 - 8 } & T4 & 42.5 & 0.02 & 0.10 & 0.002 & 0.002 & 1.39 \\
\hline \multirow{5}{*}{ SE $( \pm)$} & 6.83 & 0.21 & 2.27 & 0.005 & 0.004 & 16.34 \\
\hline C D at 5\% & Control sissoo & 85 & 2.30 & 1.40 & 0.064 & 0.049 & 79.65 \\
\cline { 2 - 8 } & T1 & 50 & 1.31 & 0.87 & 0.037 & 0.031 & 27.45 \\
\cline { 2 - 8 } & T2 & 22.5 & 0.55 & 0.61 & 0.014 & 0.021 & 4.84 \\
\cline { 2 - 8 } & T3 & 10 & 0.07 & 0.42 & 0.003 & 0.006 & 0.50 \\
\cline { 2 - 8 } & T4 & 2.5 & 0.03 & 0.20 & 0.002 & 0.001 & 0.07 \\
\hline \multicolumn{1}{|l|}{ SE $( \pm)$} & 0.59 & 0.18 & 0.069 & 0.005 & 0.007 & 6.005 \\
\hline C D at 5\% & 1.27 & 0.38 & 0.43 & 0.024 & 0.014 & 13.08 \\
\hline
\end{tabular}

Maximum inhibition was seen in Dalbergia sissoo (0.001) followed by Albizia lebbeck $(0.002)$ at $\mathrm{T}_{4}$ treatment. Maximum fresh root weight $(0.083 \mathrm{~g})$ was observed in Albizia lebbeck followed by Dalbergia sissoo $(0.049 \mathrm{~g})$ both at control (Fig.3).

\section{Vigor Index}

The vigour index of the treated tree species were seen reduced significantly as the concentration of leaf extracts increases. The statistical analysis of data revealed significant in vigor index of Albizia lebbeck and Dalbergia sissoo on different treatment (Fig. 4). The data for Albizia lebbeck (236.875) and Dalbergia sissoo (79.650) showed that maximum vigor index was observed in control. $\mathrm{T}_{4}$ treatments showed substantially lower vigor index in Dalbergia sissoo (0.075) 
than Albizia lebbeck (1.39). Das et al., (2012) reported that with the increasing the concentration of leachate of Shorea robusta, the vigour index of the Cicer aretinum decreased. The vigour index of all the four seedlings may be due to reduced seed germination and shoot length, as vigour index is the product of germination and seedling growth.

The observation of our study confirms the findings of Bansal (1998), who reported that the suppressed seed germination and seedling growth in all associated weeds and the suppressive effect increased with an increase in percent content increasing of $L$. camara extracts. The result also revealed that root elongation and lateral root developments of receptor crops were markedly inhibited compared to that of shoot elongation. Kong et al., 2007 reported that the reduction was due to the chemicals Lantadene A and Lantadene B. Shrivas \& Bajpai (1988) reported that flower extracts, followed by seed and stem extracts of Lantana indica were more inhibitory against germination, fresh and dry weight of seedling of Dalbergia sissoo.

Result showed that, different concentration of aqueous leaf extract caused reduced on shoot and root elongation as well as germination in Albizia lebbeck and Dalbergia sissoo. The harmful effect of different concentration of aqueous leaf extract is pointing out the presence of allelochemicals. The result also revealed that shoot elongation was more inhibited than root inhibition. The allelopathic chemicals causing the effect should be identified. A field study is recommended to confirm the effects of Lantana camara on field conditions with different tree species.

Present investigation conclude that aqueous extract of leaf causes suppression of germination of further growth of Albizia lebbeck and Dalbergia sissoo as compared to control. Hence effective eradication methods for this invasive alien species should be worked out in concern with forest management, natural regeneration and establishment of new seedlings of many tree species in most forests of the country.

\section{Acknowledgments}

Authors gratefully acknowledge the Dean, College of Forestry, SHUATS and Dr. Rambharose, College of Forestry, SHUATS for this work to provide facilities and support during the experiment.

\section{References}

Abdul-Baki A, Anderson JD. 1973. Vigor determination in Soybean seed by multiple criteria. Crop Sci. 13: 630-633.

Ahmed R, Uddin MB, Khan MA, Mukul SA, Hossain MK. 2007. Allelopathic effects of Lantana camara on germination and growth behavior of some agricultural crops in Bangladesh. Journal of Forest Research 18(4), 301-304.

Ambika SR, Poornima S., Palaniraj R,Sati Sc, Narwal SS (2003). Allelopathic plant Lantena camera L. Allelopathy Journal.12 (2):147-162.

Bansal, G.L. 1998. Allelopathic effect of Lantana camara on rice and associated weeds under the midhill conditions of Himachal Pradesh, India. In: Olofsdotter, M. (ed.), Proceedings of the Workshop on Allelopathy in Rice. Manila (Philippines): International Rice Research Institute. pp. 133-138

Chaudhari, B.L. and Kothari, M. (2002). Effect of Lantana camara Linn. Extract on spore germination of Bryum cellulare Hook, Allelopathy J., 9 (1) 43-52.

Das, C.R., N.K. Mondal, P. Aditya, J.K. Datta, A. Banerjee and K. Das (2012). Allelopathic potentialities of leachates of leaf litter of some selected tree 
species on gram seeds under laboratory conditions. Asian. J. Exp. Biol. Sci. 3 (1): 59-65.

Davis MA (2003) Biotic globalization: does competition from introduced species threaten biodiversity? Bioscience 53:481-489

Day M., Wiley C.J., Playford J. and Zalucki M.P. 2003. Lantana: Current Management Status and Future Prospects. ACIAR, Canberra, ACT, Australia.

Dobhal PK, Kohli RK, Batish DR. Evaluation of the impact of Lantana camara L. Invasion, on four major woody shrubs, along Nayar river of Pauri Garhwal, in Uttarakhand Himalaya. Int J Biodivers Conserv. 2010;2(7):155-61.

Fuerst, E. P. \& Putnam, A. R. 1983. Separating the competitive and allelopathic components of interference: theoretical principles. J. Chem. Ecol. 9: 937-944.

Fischer,

N.H.,Williamson,

G.

B.,Weidenhamer, J.D.\&Richardson, D. R. 1994. In search of allelopathy in the Florida scrub. The role of terpenoids. $J$. Chem. Ecol. 20: 1355-1380.

Gentle, C. B. \& Duggin, J. A. 1997. Lantana camara $L$. invasions in dry rainforestopen forest ecotones: the role of disturbances associated with fire and cattle grazing. Austr. J. Ecol. 132: 85.

Hiradate S (2006) Isolation strategies for finding bioactive compounds: specific activity vs. total activity. Am Chem Soc Symp Ser 927:113-126.

Hiradate S, Ohse K, Furubayashi A, Fujii Y (2010) Quantitative evaluation of allelopathic potentials in soils: total activity approach. Weed Sci 58:258264.

Hossain MK, Alam MN (2010) Allelopathic Effects of Lantana camara leaf extract on germination and growth behavior of some agricultural and forest crops in
Bangladesh. Pak J Weed Sci Res 16(2):217-226.

Khalaj, M. A., Amiri, M. and Azimi, M. H. (2013): Allelopathy; physiological and sustainable agriculture impact aspects. International Journal of Agronomy and Plant Production, 415: 950 - 962.

Kong, C.H., P. Wang, C.X. Zhang, M.X. Zhang and F. Hu, 2006. Herbicidal potential of allelochemicals from Lantana camara against Eichhornia crassipes and the alga Microsystis aeruginosa. Weed Res.,46: 290-295.

Leadley P., H. M. Pereira, R. Alkemade, J. F. Fernandez-Manjarrés, V. Proença, J. P. W. Scharlemann, and Walpole, M. J. 2010. Biodiversity Scenarios: Projections of 21st century change in biodiversity and associated ecosystem services. Secretariat of the Convention on Biological Diversity, Montreal. Technical Series no. 50, 132 pages.

Michelangelo Muzell Trezzi, Ribas Antônio Vidal, Alvadi Antônio Balbinot Junior, Henrique von Hertwig Bittencourt and Antonio Pedro da Silva Souza Filho (2016) Allelopathy: driving mechanisms governing its activity in agriculture, Journal of PlantInteractions, 11:1, 5360 ,

DOI:

10.1080/17429145.2016.1159342

Nandal DPS, Bisla SS, Narwal SS, Kaushik JC (1994) Allelopathic Interactions in Agroforestry Systems. In: Narwal SS, Tauro P (eds.) Allelopathy in agriculture and forestry. Scientific Publishers, Jodhpur, pp 93-1301.

Sahid, I.B. and Sugau, J.B. (1993). Allelopathic effect of lantana (Lantana camara) and Siam weed (Chromolaena odorata) on selected crops. Weed Sci., 41: 303-308.

Sharma GP, Raghubanshi AS and Singh JS (2005). Lantana invasion: an overview. Weed Biological Management (5) 157167. 
Sharma, G.P. and A.S. Raghubanshi. 2007. Effect of Lantana camara $L$. cover on plant species depletion in the Vindhyan tropical dry deciduous forest of India. Applied Ecology and Environmental Research 5:109-121.

Shrivas, R.K. and S.P. Bajpai. 1988. Effect of Lantana indica Roxb. extract on seed germination and seedling growth of Dalbergia sisso R.J. Tropical Forestry, 4(3): 256-258.

Sheoran, O.P; Tonk, D.S; Kaushik, L.S; Hasija, R.C and Pannu, R.S (1998).
Statistical Software Package for Agricultural Research Workers. Recent Advances in information theory, Statistics and Computer Applications by D.S. Hooda and R.C. Hasija Department of Mathematics Statistics, CCS HAU, Hisar (139-143).

Tilman, D. 1988. Plant strategies and the structure and dynamics of plant communities. Princeton University Press, Princeton, New Jersey.

\section{How to cite this article:}

Abha Manohar, K., Neelam Khare and Hemant Kumar. 2017. Effects of Leaf Extract of Lantana camara on Germination and Growth Behavior of Selected Tree Species. Int.J.Curr.Microbiol.App.Sci. 6(7): 2519-2526. doi: https://doi.org/10.20546/ijcmas.2017.607.297 